Ann. Biol. anim. Bioch. Biophys., I976, 16 (3), 4I3-4I9.

\title{
SOME OBSERVATIONS ON GONADOTROPHIN RELEASE IN PREGNANT AND FOETAL GUINEA PIGS
}

\author{
M. B. ter HAAR (1) \\ with the technical assistance of M. A. Harrison \\ Department of Physiology, Institute of Psychiatry, \\ De Crespigny Park, Denmark Hill, \\ London SE5 8AF (Great Britain) \\ SUMMARY
}

Guinea pig foetuses or their dams were treated with luteinizing hormone-releasing hormone (LH-RH) or saline on days $45,50,55,60$ or 65 of gestation, and serial blood samples taken from individual animals at regular intervals thereafter. After LH-RH (I ooo ng i.c.) administration to the dams, foetal gonadotrophin levels were unaffected, while maternal luteinizing hormone (LH), but not follicle-stimulating hormone (FSH), levels rose in a biphasic fashion : firstly to a plateau level of $\mathrm{I}-5 \mathrm{ng}$ NIH-LH-SI $8 / \mathrm{ml}$, then, after $20-50 \mathrm{mins}$, to preovulatory levels (I5$40 \mathrm{ng} \mathrm{LH} / \mathrm{ml}$ ).

LH-RH (200 ng i.c.) administered to the foetuses brought a rise of LH, but not FSH, levels in the foetal, but not the maternal, circulation. The time taken to reach maximal values (5-40 mins) and the increments of $\mathrm{LH}$ concentrations (r.3-Ir.3 $\mathrm{ng} \mathrm{LH} / \mathrm{ml}$ ) varied between foetuses, but could not be strictly related to the age or sex of the animal. In untreated foetuses LH and FSH were apparently secreted in an unrelated episodic fashion. Thus, the guinea-pig foetal hypophysis appears to be in an active state, at least in the later stages of gestation, while the dam is excluded from its effects by the 2-way placental barrier.

\section{INTRODUCTION}

High, but varying, levels of gonadotrophins have been recorded in the plasma of foetuses of various species including man, sheep, and cow (FOSTER et al, I972; OXENDFR, HAFS and INGalis, 1972 ; Grumbach and KaplaN, I973 ; Challis et al. r974), and, more recently, in the guinea pig (Donovan et al., I975a, $b$ ). These observations were made on single samples from separate individuals, leaving open

(1) Present Address : A. R. C. Institute of Animal Physiology, Babraham, Cambridge. 
such questions as whether the hormonal release is spontaneous, or whether it is under hypothalamic control, whether the secretion is regularly pulsatile, episodic, or continuous, whether the foetus responds to maternal releasing hormone, or vice versa, or whether the occurrence of elevated levels of hormone requires an advanced degree of maturation of the pituitary and/or its hormonal milieu. Preliminary replies to some of these questions are offered from the results described in this report.

\section{MATERIALS AND METHODS}

Pregnant albino guinea pigs as described by Donovan et al. (1975 a) were used. The day of ovulation of the cycle in which a successful mating occurred was regarded as day $\mathbf{I}$ of pregnancy.

On days $45,50,55,60$, or 65 of gestation the dams were anaesthetized with sodium pentobarbitone (Veterinary Nembutal, Abbott Laboratories; $40 \mathrm{mg} / \mathrm{kg}$ ) and placed on their backs on a heated blanket. Maternal and foetal blood samples were collected by cardiac puncture (DoNoVAN et al., I975 a). Having established the needle inside the foetal heart, less damage ensued if the needle were left in situ, and the syringe alone changed.

After a preliminary sample had been taken from the dam and each foetus (except from day 45 foetuses) either $200 \mathrm{ng}$ of synthetic luteinizing hormone-releasing hormone (LH-RH; 2 ooo $\mathrm{ng} / \mathrm{ml}$ ) was administered intracardially (i.c.) to each foetus, or I ooo ng LH-RH or $0.5 \mathrm{ml}$ saline were administered i.c. to the dam. Blood samples were then collected from the mother and each foetus at regular(usually ro min) intervals over the ensuing $\mathrm{I}-2 \mathrm{~h}$. At the end of the experiment the mother was killed by an overdose of sodium pentobarbitone, the foetuses excised, the amniotic sacs removed, and the weight, sex, and uterine position of each foetus recorded.

Subsequently the levels of LH and FSH were measured in the blood samples by heterologous radioimmunoassays employing respectively antibodies to ovine LH and rat FSH (Doxovas ct al., I975 $a, b)$.

\section{RESULTS}

The average litter size in this study was $4.3 \pm 0.2( \pm \mathrm{SEM} ; n=20)$. The average body weight $(\mathrm{g})$ at days $45,50,55,60$ and 65 of gestation for the males were $22.0 \pm \mathrm{I} .3$ ( $\pm \mathrm{SEM} ; n=4$ ), 38.I \pm I.7 (9), $47.0 \pm \mathrm{I} .8$ (II) $6 \mathrm{I} .3 \pm 2.4$ (IO), and $75.2 \pm 4.8(9)$, and for the females were $21.0 \pm 0.7(6), 33.4 \pm 1.4(7)$, $45.5 \pm 2.7(6), 55.8 \pm 3.2(12)$, and $74.0 \pm 2.39(5)$ respectively.

\section{Maternal response to $L H-R H$}

The administration of $\mathrm{I}$ ooo $\mathrm{ng}$ of $\mathrm{LH}-\mathrm{RH}$ to the mother produced a biphasic elevation of plasma levels of LH, but not FSH. The initial rise of LH occurred in the first Io mins to a plateau level of I-5 ng NIH-LH-SI $8 / \mathrm{ml}$; after $\mathrm{I}_{\mathbf{5}}-\mathbf{4 5} \mathrm{mins}$ at this level, the concentration of $\mathrm{LH}$ then rose steeply to $\mathrm{r} 5-40 \mathrm{ng} \mathrm{LH} / \mathrm{ml}$. In the example illustrated in figure $\mathrm{I}$, high levels of plasma $\mathrm{LH}$ were still apparent $3 \mathrm{~h}$ after LH-RH administration. This response was observed at all stages of pregnancy investigated (days 45 to 65 of gestation). The mothers injected with $0.5 \mathrm{ml}$ saline showed no such rise, while the foetuses under both experimental protocols showed no alteration over and above a basal fluctuation. 


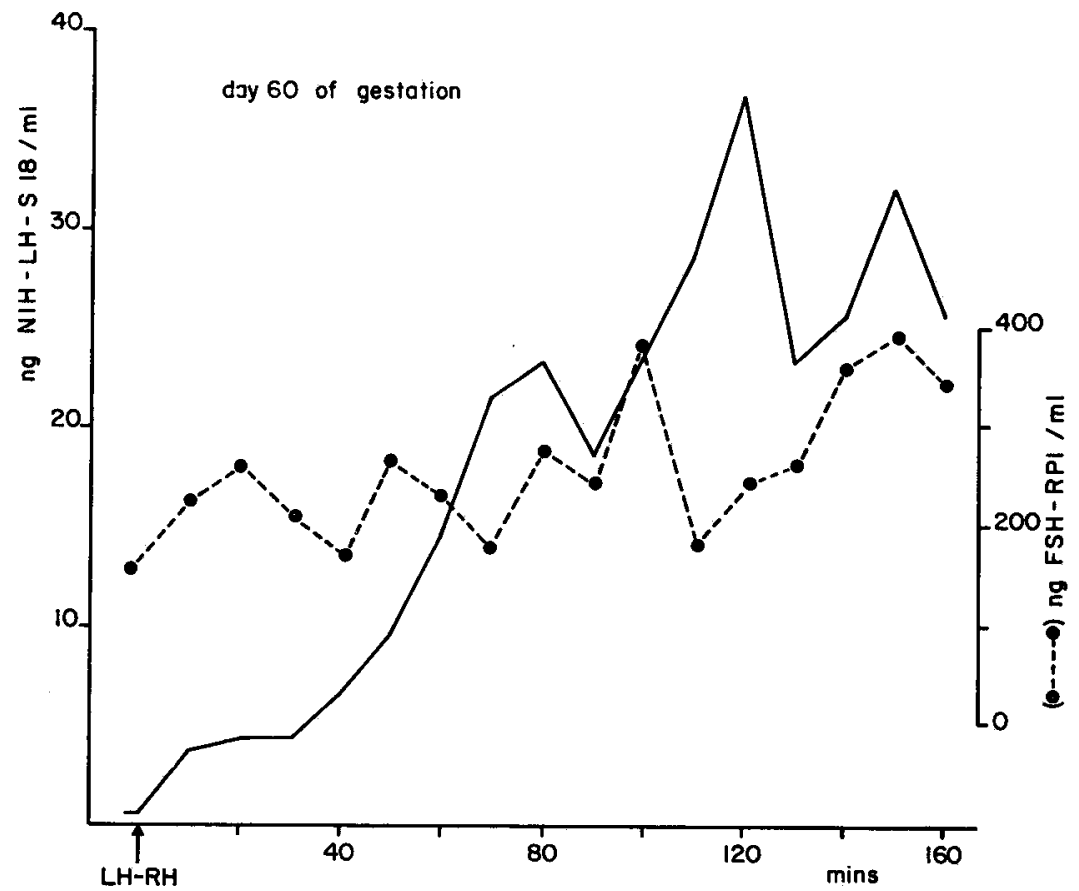

FIG. I. - Changes in the plasma concentration of LH (ng NIH-LH-Sr $8 / \mathrm{ml}$, ) and FSH (ng FSH-RPI/ml, -...-.) following the administration of $1000 \mathrm{ng}$ LH-RH to a pregnant guinea pig on day 60 of gestation

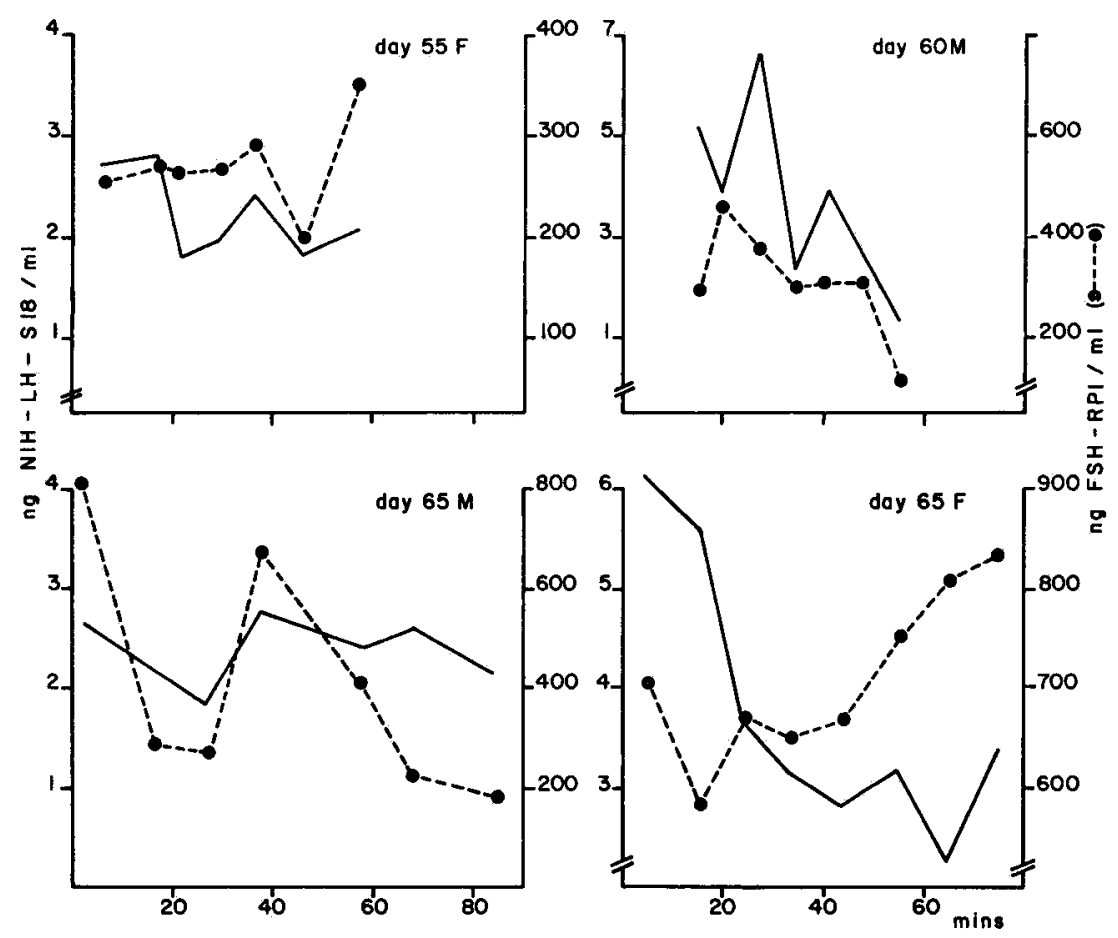

FIG. 2. - Fluctuations in plasma LH (ng NIH-LH-SI $8 / \mathrm{ml}, \ldots$ and FSH (ng FSH-RPI/ml, -...from foetuses of either sex on days 55,60 , and 65 of gestation. $\mathrm{F}$ : female; $\mathbf{M}$ : male 
M. B. TER HAAR

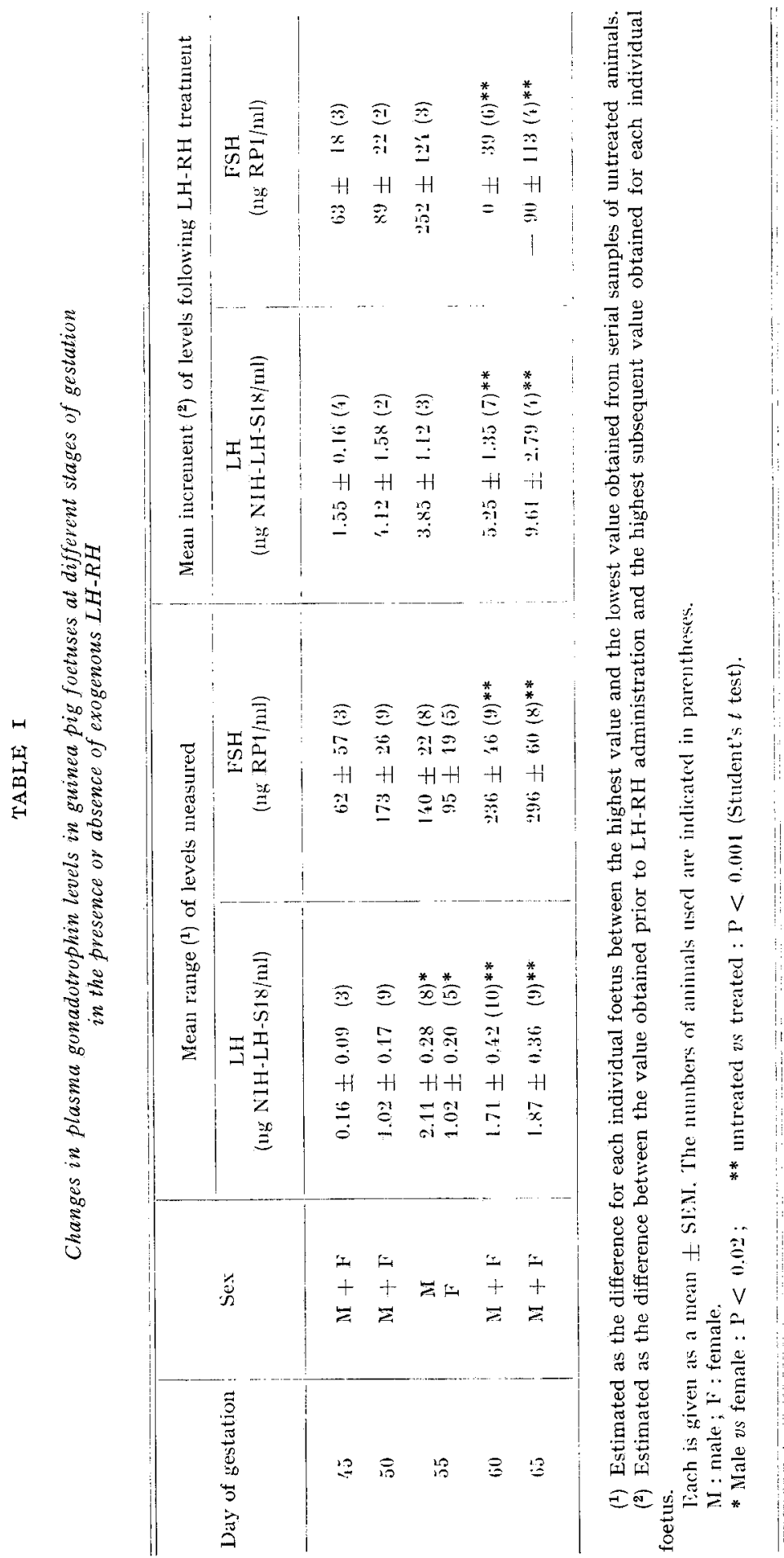




\section{Spontaneous gonadotrophin release in the foetuses}

Foetuses of either sex exhibited an episodic release of both $\mathrm{L}_{\mathrm{H}} \mathrm{H}$ and $\mathrm{FSH}$, with hormonal levels fluctuating in an arrythmic fashion (fig. 2) over considerable ranges (see table $\mathbf{I}$ ). While the range of $\mathrm{LH}_{\mathrm{H}}$ values obtained from individual animals increased as gestation progressed (from $0.16 \pm 0.90$ at day 45 to $1.87 \pm 0.36 \mathrm{ng} / \mathrm{ml}$ at day 65), there was no sex difference in the limits of this range, except at 55 day of age (table I).With respect to FSH, in both sexes the ranges were similar until day 55 of gestation, with the range widening from day 60 .

\section{Foetal response to $L H-R H$}

The foetuses, in response to $200 \mathrm{ng}$ LH-RH i.c., showed a marked rise in plasma $\mathrm{LH}$, but not FSH levels (table I), with the time taken to reach maximal levels varying from 5 to $40 \mathrm{~min}$. However, with the exception of the day 45 foetuses (which were considerably less responsive to the dose of $\mathrm{L}, \mathrm{H}-\mathrm{RH}$ ), neither the increment (ranging from I.3 to II.3 $\mathrm{ng} \mathrm{LH} / \mathrm{ml}$ ), nor the time taken to reach the maximal levels, could be strictly correlated with either the sex of the animal or with the stage of gestation. There were some indications, though, that at day 65 the foetuses might be more responsive to $\mathrm{LH}_{\mathrm{H}} \mathrm{RH}$ than at earlier stages of gestation : however, the numbers of animals available were insufficient to confirm this possibility.

There was no stimulatory effect of LH-RH on the output of FSH, and, in fact, the ranges of FSH were greatly reduced on days 60 and 65 of gestation in the $\mathrm{LH}-\mathrm{RH}$ treated foetuses as compared with those of the untreated animals. The mothers of the treated foetuses did not show evidence of any variations in the plasma concentrations of either $\mathrm{LH}$ or FSH over and above basal levels. It would appear, therefore, that guinea pig $\mathrm{LH}-\mathrm{RH}$ and gonadotrophins do not cross the placental barrier in either direction.

Throughout this study only the data from foetuses to and from which an adequate blood flow was maintained in the umbilical vessels for the duration of the experiment have been used.

\section{DISCUSSION AND CONCLUSIONS}

The response of the pregnant guinea pig to $\mathrm{LH}-\mathrm{RH}$ stimulation was rather unexpected as normally plasma $\mathrm{LH}$ levels are low during gestation (Donovan et al., I975 a). In cycling female guinea pigs the rise of $\mathrm{LH}$ in response to a single injection of $\mathrm{LH}-\mathrm{RH}$ ranges from 0.5 to $3.4 \mathrm{ng} \mathrm{LH} / \mathrm{ml}$, (Donavan and ter HaAR, 1974), and is a duration similar to that observed in other species. This increment in plasma $\mathrm{L}, \mathrm{H}$ levels in cycling animals is to a level comparable with the plateau $(\mathrm{r}-5 \mathrm{ng} / \mathrm{ml})$ observed in the pregnant animal; however in the latter animal, the processes involved in bringing about the secondary rise of $\mathrm{LH}$ levels to preovulatory levels, and in maintaining these elevated levels over an extended period, remain to be elucidated. The specific oestrogens of pregnancy in the guinea pig (Challis, HEAP and ILLINGWORTH, I97I) may have a particular role to play in this pehnomenon.

The response of the foetuses to LH-RH, especially late in gestation, is similar to that observed in the first few days after birth (Donovan, ter HAAR and PEDDIE, 
I974). In contrast, the hypophysis of the day 45 foetus is in a relatively inactive state (as judged by the lower range of gonadotrophin levels and the lesser response to LH-RH), though whether this is due to the stage of development of the pituitary or whether it is due to the absence of a stimulatory hormonal milieu, which may appear later in gestation, remains unclear.

That the foetal hypophysis is responsive to LH-RH stimulation does not necessarily indicate that the fluctuations in both $\mathrm{LH}$ and FSH levels in the untreated foetuses are under hypothalamic control. In contrast with the human (GrBBons, MirnICK and CHIEFFo, I975), neither the amniotic fluid nor the placenta of the guinea pig contain $\mathrm{LH}_{\mathrm{H}}$ or FSH releasing material, nor do they contain a gonadotrophin which cross reacts in the immunoassays used in the present study (M. B. ter HAAR, unpublished observations). Thus it would appear that, if the fluctuations in gonadotrophin levels in the foetus are not spontaneous, they are under the control of the hypothalamus.

The varying levels of the foetal gonadotrophins account for the wide distribution of the levels of these hormones previously reported in individual animals (DoNOvan et al., I975 $a, b$ ). However, at present the role of these relatively high levels of foetal hormones is uncertain, as destruction of the foetal pituitary gland by electrolytic lesions does little to impair gonadal development (DoNovax, ter HAAR and PEDDIE, I974). The elevated levels may represent a stimulatory effect of certain maternal steroids or, alternatively, insufficient development of a gonadal-hypothalamic control of the pituitary.

It is of interest that the placenta apparently acts as an effective two way barrier to the passage of proteinaceous hormones in the form of $\mathrm{LH}-\mathrm{RH}$ and gonadotrophins, while steroidal hormones do appear to have at least some ability to cross this barrier (Donovan, ter HAAR and PEDDIE, r974).

Sexual Maturation 3rd Workshop August 31, september $3,1975$.

\section{ACKNOWLEDGEMENTS}

This work was supported by a grant (G. 973/809/C) from the MI. R. C. to Professor B. T. DoNovan. I should like to thank Professor G. D. NIswender for the anti-ovine LH serum No. I 5 , Professor L. E. ReicheRT, Jr., for the purified LH (LER-1056-C2) for iodination, the Endocrinology Study Section of the NIH for the standard preparation of ovine luteinizing hormone, NIH-LH-Si 8, and the National Institute of Arthritis, Metabolism and Digestive Diseases, Rat Pituitary Program, for the materials for the rat $\mathrm{FSH}$ assay.

\section{RÉSUMÉ}

\section{I,IBÉRATION DES GONADOTROPHINES}

CHEZ LE FGETUS DE COBAYE ET SA MÈRE

Des fœtus de Cobaye ou les mères reçoivent du LH-RH au $45^{\mathrm{e}}, 5 \mathrm{O}^{\mathrm{e}}, 55^{\mathrm{e}}, 6 \mathrm{o}^{\mathrm{e}}$, ou $65^{\mathrm{e}}$ jour de gestation. Après injection de $\mathrm{I}$ ooo $\mathrm{ng}$ de LH-RH à la mère, les taux de gonadotrophines fœetales ne sont pas modifiées, alors que la LH maternelle (pas la FSH) s'élève jusqu'à I-5 ng/ml, puis après 20-50 $\mathrm{mn}$ atteint des niveaux préovulatoires $(\mathrm{I} .5-40 \mathrm{ng} / \mathrm{ml}$ ). 
Après injection de $200 \mathrm{ng}$ de LH-RH au foetus, les gonadotropines maternelles ne sont pas modifiées, mais la LH (pas la FSH) foetale augmente. Le temps nécessaire pour arriver à l'élévation maximale et l'importance de l'augmentation de la LH sont variables entre les fœetus mais ne peuvent être reliés ni à leur âge, ni à leur sexe.

Chez le fœetus $\mathrm{LH}$ et FSH semblent être sécrétés de manière épisodique sans relation entre elles. L'hypophyse fotale apparaît donc fonctionnelle, au moins dans les derniers stades de la gestation, et la mère est protégée de ses effets, dans les 2 sens, par la barrière placentaire.

\section{REFERENCES}

Challis J. R. G., Heap R. B., Illingworth D. V., I97I. Concentration of oestrogen and progesterone in the plasma of non-pregnant, pregnant and lactating guinea-pigs. J. Endocr., 51, 333-345.

Challis J. R. G., Kim C. K., Nafrolin F., Judd H, L., Yen S. S. C., Benirschke K., I974. The concentrations of androgens, oestrogens, progesterone and luteinizing hormone in the serum of foetal calves throughout the course of gestation. J. Endocr., 60, ro7-II5.

Donovan B. T., ter HAAR M. B., 1974. Luteinizing hormone and follicle-stimulating hormone secretion in response to luteinizing hormone releasing hormone in the adult guinea-pig. J. Endocr., 63, $34 \mathrm{P}$. (Abstract).

Donovan B. T., ter HaAR M. B., Peddie M. J., I974. Pituitary-gonadal interaction in the foetal and neonatal guinea-pig. Coll. I.N.S.E.R.M., 32, І6г-г76.

Donovan B. T., ter HaAR M. B., Lockhart A. N., Mackinnon P. C. B., Mattock J. M., Peddie M. J., I975 a. Changes in the concentration of luteinizing hormone in plasma during development in the guinea-pig. J. Endocr., 64, 5I I-520.

Donovan B. T., ter HaAr M. B., Lockhart A. N., Peddie M. J., I975 $b$. Changes in the concentration of follicle-stimulating hormone in plasma during development in the guinea-pig. J. Endocr., 64, $52 \mathrm{I}-528$.

Foster D. L., Roach J. F., Karsch F. J., Norton H. W., Cook B., Nalbanuov A. V., I972. Regulation of luteinizing hormone in the fetal and neonatal lamb. I. LH concentrations in the blood and pituitary. Endocrinology, 90, IO2-III.

Gibbons J. M., Mitnick M., Chieffo V., I975. In vitro biosynthesis of FSH and LH-releasing factors by the human placenta. Am. J. Obstet. Gynecol., 121, I27-1 3 I.

Grumbach M. M., KaplaN S. L., 1973. Ontogenesis of growth hormone, insulin, prolactin and gonadotropin secretion in the human foetus : Foetal and neonatal physiology, Barcroft Centenary Symposium p. 462-487, Eds. K. S. Comline, K. W. Cross, G. S. Dawes and P. W. Nathanielsz. Cambridge University Press.

Oxender W. D., Hafs H. D., Ingales W. G., I972. Serum growth hormone, LH and prolactin in the bovine fetus and neonate. J. Anim. Sci., 35, 56-6r. 